\title{
THE SYNTHESIS OF $\mathrm{PbZr}_{0.52} \mathrm{Ti}_{0.48} \mathrm{O}_{3}$ AND $\mathrm{PbZr}_{0.58} \mathrm{Ti}_{0.42} \mathrm{O}_{3}$ CERAMIC POWDER BY MOLTEN SALT METHOD AND ITS INTERMEDIATE PRODUCT ANALYSIS
}

\section{SINTESA SERBUK KERAMIK PbZr ${ }_{0.52} \mathrm{Ti}_{0.48} \mathrm{O}_{3}$ DAN PbZr $\mathrm{P}_{0.58} \mathrm{Ti}_{0.42} \mathrm{O}_{3}$ DENGAN METODE MOLTEN SALT DAN ANALISA PRODUK INTERMEDIETNYA}

\author{
Syahfandi Ahda, Mardiyanto, Agus Taufiq, Marzuki Silalahi
}

Centre for Science Technology of Advanced Materials, National Nuclear Energy Agency, Kawasan Puspiptek, Tangerang Selatan. e-mail: idnafahda@gmail.com, panitra@batan.go.id, agustaufiq@batan.go.id, silalahimarzuki@gmail.com

\begin{abstract}
Lead zirconate titanate, $\mathrm{Pb}\left(Z r_{1-x}, \mathrm{Ti}_{x}\right) \mathrm{O}_{3}$ is a material with high piezoelectric properties and many studies have been carried out in its development, in order to improve the materials quality in various applications. One of the developments in the synthesis of piezoelectric material is also carried out using the Molten Salt method. Due to the advantages of this method in preparing materials are simpler and less expensive. The aim of this study was to obtain the optimal synthesis parameters of $\mathrm{Pb}\left(\mathrm{Zr1}-\mathrm{x}, \mathrm{Ti}_{\mathrm{x}}\right) \mathrm{O}_{3}$ material using Molten Salt method and then proceed to identify and analyse synthesis and intermediate products for each synthesis parameter applied. The ratio of $\mathrm{NaCl} / \mathrm{KCl}$ salt at $1: 1$ in moles as a solvent medium was carried out in synthesizing $\mathrm{PbZr}_{0.52} \mathrm{Ti}_{0.48} \mathrm{O}_{3}$ and $\mathrm{PbZr}_{0.58} \mathrm{Ti}_{0.42} \mathrm{O}_{3}$. Likewise, the ratio of salt to reactants/ base material is $1: 1$ in weight percentages. Whereas intermediate products are obtained if the dynamics of chemical reactions in the diffusion process can occur indirectly or gradually. To identify intermediate products in this synthesis process, the sintering temperature was varied from 575,675 and $775^{\circ} \mathrm{C}$ for samples $A, B$ and $C$, respectively. The results of this synthesis have been identified and characterized using the $X$-ray diffraction (XRD) method. The High score program using the Rietveld method can identify the content of synthesized and intermediate products by conducting a refinement process on the XRD intensity profile. Indications of good results on the refinement process are shown with statistical errors of less than 6\%. Intermediate products from samples $A$ and $B$ were obtained as follows, $\mathrm{PbTiO}_{3}, \mathrm{PbZrO}_{3}$ and $\mathrm{Zr}_{0.4} \mathrm{Ti}_{0.6} \mathrm{O}_{3}$. Whereas sample $\mathrm{C}$ has been obtained in two phases, namely $\mathrm{PbZr}_{0.52} \mathrm{Ti}_{0.48} \mathrm{O}_{3}$ and $\mathrm{PbZr}_{0.58} \mathrm{Ti}_{0.42} \mathrm{O}_{3}$ with tetragonal structure (P4mm) and rhombohedral crystal (R3c). While the optimal parameters of sample $C$, as a synthesis product, have been obtained by grinding for 4 hours and sintering temperature of $775^{\circ} \mathrm{C}$ for 4 hours.
\end{abstract}

Key Words: Molten Salt Method, Intermediate products

\begin{abstract}
Abstrak
Lead zirconate titanate, $\mathrm{Pb}\left(\mathrm{Zr}_{1-\mathrm{x}}, \mathrm{Ti}_{\mathrm{x}}\right) \mathrm{O}_{3}$ merupakan bahan dengan sifat piezoelektrik yang tinggi dan telah banyak penelitian dilakukan dalam pengembangannya, agar dapat meningkatkan kualitas bahan dalam berbagai aplikasi. Salah satu pengembangan dalam sintesa bahan piezoelektrik adalah metode Molten Salt yang juga dilakukan pada penelitian kali ini. Karena kelebihan metode ini dalam menyiapkan bahan keramik adalah lebih sederhana dan lebih murah. Tujuan dari penelitian ini adalah untuk mendapatkan parameter sintesa secara optimal dari material $\mathrm{Pb}\left(\mathrm{Zr}_{1-x}, \mathrm{Ti}_{\mathrm{x}}\right) \mathrm{O}_{3}$ dengan menggunakan metode Molten Salt dan kemudian dilanjutkan untuk
\end{abstract}


mengidentifikasi dan menganalisa produk sintesa dan intermediete (antara) untuk setiap parameter yang diterapkan. Rasio garam $\mathrm{NaCl} / \mathrm{KCl}$ pada $1: 1$ dalam mol sebagai media pelarut dalam mensintesa $\mathrm{PbZr}_{0.52} \mathrm{Ti}_{0.48} \mathrm{O}_{3}$ dan $\mathrm{PbZr}_{0.58} \mathrm{Ti}_{0.42} \mathrm{O}_{3}$. Demikian juga, perbandingan garam dengan reaktan/ material dasar adalah $1: 1$ dalam persentase berat. Sedangkan produk intermediet diperoleh jika dinamika reaksi kimia dalam proses difusi dapat terjadi secara tidak langsung atau bertahap. Untuk mengidentifikasi produk dan intermediet dalam proses sintesa ini, suhu sintering divariasikan dari 575,675 dan $775{ }^{\circ} \mathrm{C}$ bagi masing-masing sampel A, B dan C. Hasil sintesa ini telah diidentifikasi dan dikarakterisasi dengan menggunakan metode difraksi sinar-X (XRD). Program Highscore dengan menggunakan metode Rietveld dapat mengidentifikasi konten produk sintesa dan intermediet dengan melakukan proses refinement pada profil intensitas XRD. Indikasi hasil yang baik pada proses refinement ditunjukkan dengan kesalahan statistik kurang dari $6 \%$. Produk intermediet dari sampel A dan B telah diperoleh sebagai berikut, $\mathrm{PbTiO}_{3}, \mathrm{PbZrO}_{3}$ dan $\mathrm{Zr}_{0.4} \mathrm{Ti}_{0.6} \mathrm{O}_{3}$. Sedangkan parameter optimal sampel $\mathrm{C}$, sebagai produk sintesa, telah diproleh untuk penggerusan sampel selama 4 jam dan suhu sintering $775^{\circ} \mathrm{C}$ selama 4 jam.

Kata kunci : Metode Molten Salt, Produk intermediet/antara

Diterima (received ) : 17 Juli 2019 , Direvisi (revised ) : 21 Oktober 2019 ,

Disetujui (accepted) : 04 November 2019

\section{INTRODUCTION}

Lead zirconate titanate, symbolized by $\mathrm{Pb}\left(\mathrm{Zr}_{1-\mathrm{x}}, \mathrm{Ti}_{\mathrm{x}}\right) \mathrm{O}_{3}$ or namely $\mathrm{PZT}$, is one of the most popular and most studied piezoelectric materials in the last decade. Therefore, this material itself has been widely applied, especially as a sensor or low power generator or harvesting energy, because this material has excellent dielectric, ferroelectric and piezoelectric properties ${ }^{1}$. In improving the quality of material functions, it is necessary to study the synthesis process, in order to obtain higher material properties. Currently the synthesis of piezoelectric materials with various methods has been carried out, such as solid state reaction, sol gel, hydrothermal and Molten Salt methods. Especially for the Molten Salt method, many researchers and industrialists have used it to fabricate ceramic powder materials, including the synthesis of piezoelectric, $\quad(\mathrm{Bi}, \mathrm{Pb})-\mathrm{Ca}-\mathrm{Sr}-\mathrm{Cu}-\mathrm{O}$ superconducting materials ${ }^{2}$, $p$-Type $\mathrm{CaFe}_{2} \mathrm{O}_{4}$ semiconductor nanorods ${ }^{3,4)}$. The development of Molten Salt technology has been applied to study for nuclear fuel processing and spent fuel recycling, as was done by Sylvie Delpech5).

Especially the Molten Salt method is a modification of the powder metallurgical method. Salts with a low melting point is added to the reactants and then heated above the melting point of the salt. The basic materials as reactants are reacted in an atmosphere of salt solution, whereas salts function only as a catalyst or solvent. The types of salt mixtures that are commonly used are such as sulphate and chloride ${ }^{6,7)}$. Therefore it can be prepared easily and applied in the form of ceramic polycrystalline samples.

Molten Salt technique is a simple and inexpensive technology to make new ceramic materials, (including one of them is PZT) by mixing stoichiometric oxides and followed by the sintering process at high temperatures in an atmosphere of salt solution. Sintering process is the main step of this technique, because some reaction mechanisms can occur from oxide components, including the diffusion process plays an important role, resulting in the formation of rather homogeneous compound ${ }^{8)}$.

The formation of $\mathrm{Pb}\left(\mathrm{Zr}_{1-\mathrm{x}}, \mathrm{Ti}_{\mathrm{x}}\right) \mathrm{O}_{3}$ compounds with its reaction stages using Molten Salt method under variations of sintering temperature are the objectives of this study. This synthesis products were identified and characterized using X-ray diffraction (XRD) method and analysed its crystal structure using the Highscore program. Therefore, the study is attempted to describe and to explain the thermal conditions which govern the phase PZT formation of pure and intermediate products. Knowing intermediate products is a dynamic of a chemical reaction process that is not directly available. This intermediate product in this study was formed by varying the sintering temperature.

\section{METHODOLOGY}

The PZT synthesis that has been carried out is using the basic/ reactant materials of $\mathrm{PbO}$ (Aldrich with purity of $99.997 \%$ ), $\mathrm{ZrO}_{2}$ and $\mathrm{TiO}_{2}$, while as solvent salt comes from $\mathrm{NaCl}$ 
The Synthesis of $\mathrm{PbZr}_{0.52} \mathrm{Ti}_{0.48} \mathrm{O}_{3}$ and $\mathrm{PbZr}_{0.58} \mathrm{Ti}_{0.42} \mathrm{O}_{3}$ Ceramic Powder by Molten Salt Method and Its Intermediate Product Analysis(Syahfandi Ahda, Mardiyanto, Agus Taufiq, Marzuki Silalahi

and $\mathrm{KCl}$ with a mole ratio of $1: 1$. Generally to produce liquid phase temperature eutectic salt mixtures are used. For example $\mathrm{NaCl}$ and $\mathrm{KCl}$ melts at 801 and $770^{\circ} \mathrm{C}$, respectively, while the eutectic salt composition of $\mathrm{NaCl}-\mathrm{KCl}$ $(0.5 \mathrm{NaCl}-0.5 \mathrm{KCl})$ melts at $\left.658^{\circ} \mathrm{C}{ }^{4}\right)$.

In this study, complex oxide powder of $\mathrm{Pb}\left(\mathrm{Zr}_{0,52} \mathrm{Ti}_{0,48}\right) \mathrm{O}_{3}$ was prepared from the reactants with the following procedure. The reactant mixture and salt are mixed and crushed for 3-4 hours and then heated above the melting temperature of the salt $\left(775^{\circ} \mathrm{C}\right.$ is called sintering). At this heating temperature, the salt melts and reacts between reactants and product particles form. Powder characteristics of the product are controlled by choosing temperature, heating duration and weight ratio of salt content with the number of reactants.

Then, the reacted mass is cooled to room temperature and washed with an appropriate solvent (usually, hot/boiling water) to remove salt. Complex oxide powder is obtained after drying.

Besides synthesizing above the melting point of salt, this study was also applied to the bottom or close to its melting point in order to get the formed stages of the reaction with temperature variations. Likewise, it also varies the ratio between salt and reactants. For more details, these experimental steps can be named as sample labels and shown in the table below. However, each sample is heated for 4 hours.

Table 1.

Variations for several experimental parameters using Molten Salt technique

\begin{tabular}{cc}
\hline Sample & Sintering temperature $\left[{ }^{\circ} \mathrm{C}\right]$ \\
\hline $\mathrm{A}$ & 575 \\
$\mathrm{~B}$ & 675 \\
$\mathrm{C}$ & 775 \\
\hline
\end{tabular}

The sintering temperature of sample $A$ that was applied was below the melting point temperature of the liquid salt $\mathrm{NaCl}-\mathrm{KCl}$ $\left(675^{\circ} \mathrm{C}\right)$, sample $\mathrm{B}$ was at the melting point of salt, while sample $C$ was far above it.

Identification of the synthesis results has been done using $\mathrm{X}$-ray diffraction machines and continued with crystal structure analysis using software of Highscore based on the Rietveld program.

\section{RESULT AND DISCUSSION}

In this study, samples A and B were analysed in detail first, because the sintering temperature was close to the melting temperature of $\mathrm{NaCl}-\mathrm{KCl}$, then the sample $\mathrm{C}$ was analysed further. All XRD patterns were recorded for characterization at room temperature using a PW1710 type PANalytycal EMPYREAN XRD machine by employing CuKa radiation. Some of these XRD patterns recorded for several compounds (for example) are shown in the figure 1. For samples with sintering temperatures of $575{ }^{\circ} \mathrm{C}$ (sample A) and $675^{\circ} \mathrm{C}$ (sample B), as be done by Laras ${ }^{9}$. The initial refinement was carried out by zeropoint shift, background and unit-cell parameters. Samples A and B have shown many contaminant peaks, in addition to the presence of PZT peaks. Therefore, the possibility of the presence of basic material peaks (some have not reacted) and other compounds peaks, such as $\mathrm{PbZrO}_{3}, \mathrm{PbTiO}_{3}$ and $\mathrm{ZrTiO}_{3}$ can be used as inputs to the refinement process (Figure 2).

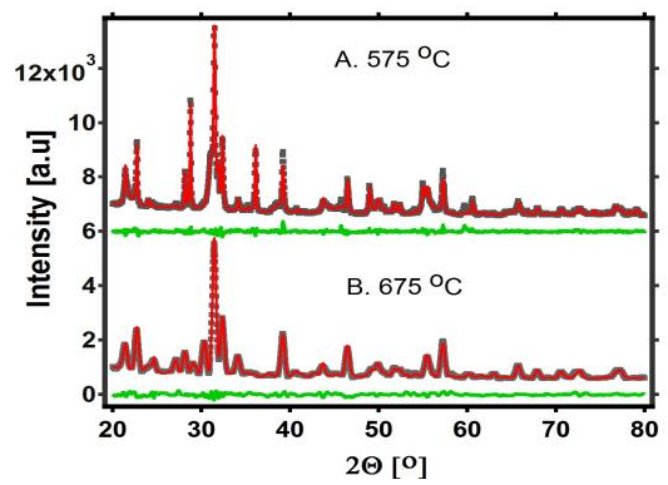

Figure 1.

Profile of XRD intensity on samples A and B and intensity of refinement results.

The black dot is experimental data, the red line is the result of fitting and the green line is the difference from the experimental data with the calculating data from the fitting process.

In Figure 1 shows also the results of the intensity profile of the refinement process using the Highscore program (red line) and differences with experimental data (green lines). While the experimental data itself is indicated by black dot. Sample A at sintering temperature $575{ }^{\circ} \mathrm{C}$ shows many different intensity peaks with sample $B$ at sintering temperature of $675^{\circ} \mathrm{C}$, both the height of XRD intensity and position at the peak of the diffraction angle. With a note that the temperature of $575^{\circ} \mathrm{C}$ is below the Molten Salt temperature $(\mathrm{NaCl}-\mathrm{KCl})$, still relatively solid, while the temperature of $675^{\circ} \mathrm{C}$ is close to the melting point of salt, relatively soft or liquid.

The feasibility of this refinement process is indicated by the final statistical indicators, including the profile factor, $R_{p}$, and the weighted profile factor, $R_{w p}$. The quality of refinement is verified by this two factors, $R_{P}$ and RwP, comparative parameters between theoretical and experimental XRD patterns, 
which can be used to monitor the convergence of the model. $R_{p}$ and $R_{w p}$ should reach a value of $R_{\operatorname{EXP}}$ (the expected value of the error) to consider the model acceptable. The value of RwP for good results is $2-10 \%$ 10, 11).

As we know this method (HighscoreRietveld) that in order to get the calculation (theoretical) curve to approach the experimental curve, it has been repeated smoothing of least squares to obtain the best match between experimental and calculation data. This has been done by changing the factors of instrumentation, peak profiles and occupancy of the constituent atoms.

Table 2.

The profile factor $(\mathrm{Rp})$ and the weighted profile factor (Rwp) as the final statistical indicators of the refinement process for samples $A$ and $B$.

\begin{tabular}{ccc}
\hline & $\mathrm{R}_{\mathrm{p}}[\%]$ & $\mathrm{R}_{\mathrm{wp}}[\%]$ \\
\hline Sample A & 3.866 & 5.069 \\
Sample B & 4.3607 & 5.6068 \\
\hline
\end{tabular}
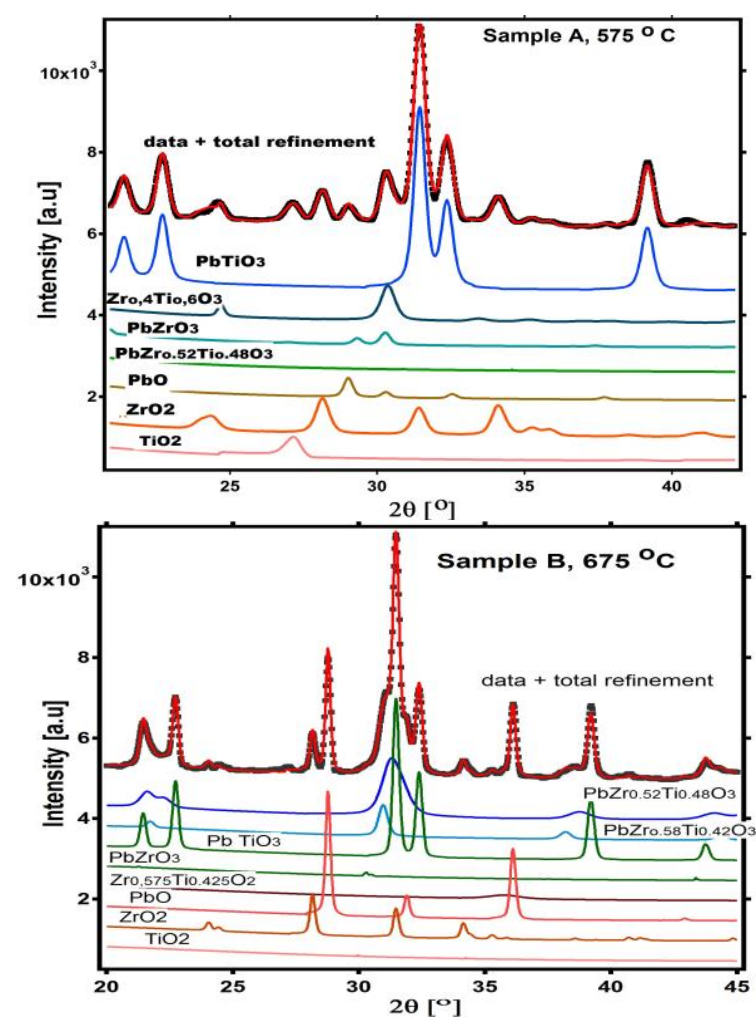

Figure 2.

Results of refinement intensity profiles on sample $A$ (at sintering temperature $575^{\circ} \mathrm{C}$ ) and $B\left(\right.$ at $675^{\circ} \mathrm{C}$ ) with various phases of the basic materials and the intermediation reaction products. The black dot represents experimental intensity and the red line is the total intensity of the refinement on the top profile.
The final results of this improvement exhibit a good agreement in the refinement process with a value of $R_{p}$ and $R_{w p}$ below $6 \%$, see Table 2. For more detailed analysis, we zoom in on Figure 1. From angles 20 to $45^{\circ}$, as seen in Figure 2. Each of the compounds inputted in the refinement process and contributes to the results of the refinement, is also graphed in Figure 2.

As shown in Figure 2, both $x$-ray diffraction intensity profiles (samples $A$ and $B$ ) show significant differences, both diffraction angles and high-low intensities. In figure 2 also shows the refinement results in detail with some phases formed from solid reactions. The peak profiles of the structure of $\mathrm{PbO}, \mathrm{ZrO}_{2}$ and $\mathrm{TiO}_{2}$ as the basic materials have already existed at sintering temperatures of 575 and $675{ }^{\circ} \mathrm{C}$. By entering structural data from $\mathrm{PbTiO}_{3}, \mathrm{PbZrO}_{3}, \quad \mathrm{Zr}_{0.4} \mathrm{Ti}_{0.6} \mathrm{O}_{3}, \mathrm{PbZr}_{0.52} \mathrm{Ti}_{0.48} \mathrm{O}_{3}$ and $\mathrm{PbZr}_{0.58} \mathrm{Ti}_{0.42} \mathrm{O}_{3}$ (which are possible) as input in the refinement process, those have shown that the fittings process can be improved, in addition to the expected reaction results. With the data as an output from the results of the refinement, it can be shown in the table 3 .

Table 3.

The basic materials, Intermediate and expected product contents which are the results of refinement on the Rietveld method using the Highscore program

\begin{tabular}{|c|c|c|c|}
\hline \multirow[b]{2}{*}{ Products } & \multicolumn{2}{|c|}{ Weight fraction [\%] } & \multirow{2}{*}{$\begin{array}{l}\text { Space } \\
\text { group } \\
\text { used }\end{array}$} \\
\hline & $\begin{array}{c}\text { in } \\
\text { sample } \\
\text { A }\end{array}$ & $\begin{array}{c}\text { in sample } \\
\text { B }\end{array}$ & \\
\hline $\mathrm{TiO}_{2}$ & $16(2)$ & $0.3(2)$ & $\mathrm{P} 121 / \mathrm{c} 1$ \\
\hline $\mathrm{ZrO}_{2}$ & $32.0(3)$ & $24(1)$ & $\mathrm{P} 121 / \mathrm{c} 1$ \\
\hline $\mathrm{PbO}$ & $1.7(2)$ & 11.7(2) & $\mathrm{Cmma}$ \\
\hline $\mathrm{PbZrO}_{3}$ & $1.4(2)$ & $0.34(9)$ & Pba2 \\
\hline $\mathrm{PbTiO}_{3}$ & $32.0(2)$ & $31.1(1)$ & $\mathrm{P} 4 \mathrm{~mm}$ \\
\hline $\mathrm{Zr}_{0.4} \mathrm{Ti}_{0.6} \mathrm{O}_{3}$ & $16(1)^{\prime}$ & $1(4)$ & Pbcn \\
\hline $\mathrm{PbZr}_{0.52} \mathrm{Ti}_{0.48} \mathrm{O}_{3}$ & $0.03(3)$ & $26(1)$ & $\mathrm{P} 4 \mathrm{~mm}$ \\
\hline $\mathrm{PbZr}_{0.58} \mathrm{Ti}_{0.42} \mathrm{O}_{3}$ & 0 & $5.9(5)$ & $\mathrm{R} 3 \mathrm{~m}$ \\
\hline
\end{tabular}

Increasing the temperature until the sintering state was $575{ }^{\circ} \mathrm{C}$, holding up to 4 hours, and then decreasing to room temperature, as done in sample $A$, the transformations of solid reactions have not shown PZT products, but producing dominant intermediate products including $\mathrm{PbTiO}_{3}$, $\mathrm{PbZrO}_{3}$ and $\mathrm{Zr}_{0.4} \mathrm{Ti}_{0.6} \mathrm{O}_{3}$, as mentioned also by Necira ${ }^{12)}$. As for the experimental parameters equal to sample $A$, sample $B\left(675^{\circ} \mathrm{C}\right)$ has shown the same intermediate product and also has clearly produced the expected products, such as $\mathrm{PbZr}_{0.52} \mathrm{Ti}_{0.48} \mathrm{O}_{3}$ and $\mathrm{PbZr}_{0.58} \mathrm{Ti}_{0.42} \mathrm{O}_{3}$. A note is that the content of the reactant 
The Synthesis of $\mathrm{PbZr}_{0.52} \mathrm{Ti}_{0.48} \mathrm{O}_{3}$ and $\mathrm{PbZr}_{0.58} \mathrm{Ti}_{0.42} \mathrm{O}_{3}$ Ceramic Powder by Molten Salt Method and Its Intermediate Product Analysis(Syahfandi Ahda, Mardiyanto, Agus Taufiq, Marzuki Silalahi

materials decreases and PZT products begin to form, while the intermediate $\mathrm{Zr}_{0.4} \mathrm{Ti}_{0.6} \mathrm{O}_{3}$ product drops sharply at $675^{\circ} \mathrm{C}$.

The basic/ reactant materials in this study are oxide materials, like $\mathrm{PbO}, \mathrm{ZrO}_{2}$ and $\mathrm{TiO}_{2}$. So that the reaction transformations that occur by the initial mixed oxides during its heat treatment can occur simply or complex depending on the nature and reactivity of the starting oxides (purity, structure, grain size ${ }^{13}$ ), as done by Venkataramani $S$ and explained again by Necira $Z^{12)}$.

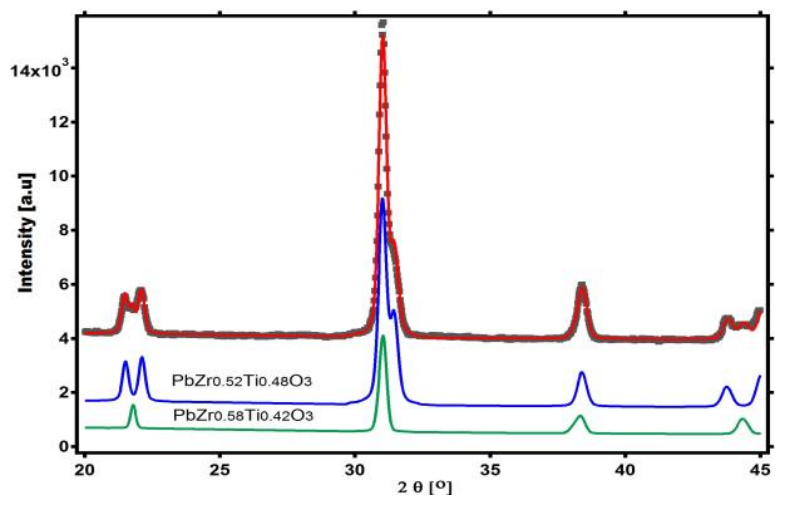

Figure 3.

Refinement intensity results of sample $C$ with sintering temperature of $775^{\circ} \mathrm{C}^{\text {9). }}$. Green line represents the result of refinement intensity for $\mathrm{PbZr}_{0.58} \mathrm{Ti}_{0.42} \mathrm{O}_{3}$ crystal, blue line for $\mathrm{PbZr}_{0.52} \mathrm{Ti}_{0.48} \mathrm{O}_{3}$ crystal, red line for total refinement and black dot is the experiment intensity.

In this study to obtain the expected homogeneous PZT product, the sintering temperature was raised to $775^{\circ} \mathrm{C}$ for sample $\mathrm{C}$, as shown in the XRD Intensity profile in figure 3. The peaks of the basic material and intermediate products have been completely disappeared but all the peaks strongly indicate the presence of diffraction patterns of PZT crystals.

The refinement process on XRD intensity from sample $C$ has been done by getting a good statistical error of Rp and Rwp are 5.2204 da $6.7477 \%$, where the content of $\mathrm{PbZr}_{0.52} \mathrm{Ti}_{0.48} \mathrm{O}_{3}$ and $\mathrm{PbZr}_{0.58} \mathrm{Ti}_{0.42} \mathrm{O}_{3}$ is 75.2 and 24.8 in percentage weight, respectively. This composition is diphase structurally (the tetragonal phase (P4mm) and the rhombohedral phase (R3c)). From these figures it was found that PZT perovskite phase with co-existence of both tetragonal and rhombohedral phases matching with the JCPDS file no. 33-0784 and 73-2022, respectively11). With the presence of concentrations of these intermediate phases, specifically $\mathrm{PbTiO} 3$ and $\mathrm{PbZrO} 3$, the structural phase transition of $\mathrm{R} 3 \mathrm{~m}$ in $\mathrm{P} 4 \mathrm{~mm}$ or reversed (morphotropic phase transition) takes place in this solid solution. This phase transition is also supported by the diagram phase of PZT itself which is determined from the $\mathrm{PbTiO}_{3}$ and $\mathrm{PbZrO}_{3}$ materials.
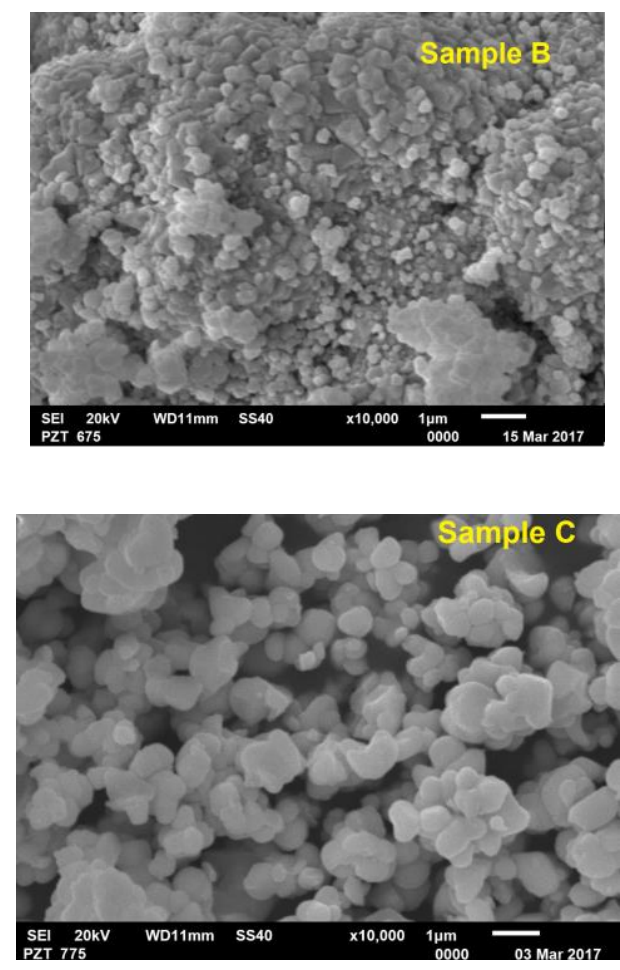

Figure 4.

Powdered SEM micrographs sintered at different temperatures of $675^{\circ} \mathrm{C}$ for samples $\mathrm{B}$ and $775^{\circ} \mathrm{C}$ for samples $\mathrm{C}$

In the figure 4, powder particle morphology is compared between sample B and C. It can be noted that the increase in sintering temperature causes an increase in particle size at 4 hours isothermal time. In sample B (675 $\left.{ }^{\circ} \mathrm{C}\right)$ particles showed agglomeration, particle sizes varied and were not homogeneous, while sample $B\left(775^{\circ} \mathrm{C}\right)$ was almost the same and homogeneous. In the micrograph above it is very complementary with the presence of many phases in sample B and only two phases for sample $C$. In the micrograph above it is very complementary with the presence of many phases in sample B and only two phases for sample $\mathrm{C}$.

\section{CONCLUSION}

The synthesis using the Molten Salt method to obtain PZT material was successfully carried out with a ratio of $1: 1$ mixture of $\mathrm{NaCl}-\mathrm{KCl}$ salt to the base material and several stages of sintering temperature. Likewise, materials $\mathrm{PbTiO}_{3}, \mathrm{PbZrO}_{3}$ and 
$\mathrm{Zr}_{0.4} \mathrm{Ti}_{0.6} \mathrm{O}_{3}$ as synthesis products at sintering temperatures $575{ }^{\circ} \mathrm{C}$ and $675{ }^{\circ} \mathrm{C}$ indicated strongly as intermediate products. Materials $\mathrm{PbZr}_{0.52} \mathrm{Ti}_{0.48} \mathrm{O}_{3}$ and $\mathrm{PbZr}_{0.58} \mathrm{Ti}_{0.42} \mathrm{O}_{3}$ which have a tetragonal (P4mm) and rhombohedral crystal structure (R3c) as the expected product have been obtained at sintering temperatures of 775 ${ }^{\circ} \mathrm{C}$. The particle sizes $\mathrm{PbZr}_{0.52} \mathrm{Ti}_{0.48} \mathrm{O}_{3}$ and $\mathrm{PbZr}_{0.58} \mathrm{Ti}_{0.42} \mathrm{O}_{3}$ in $\mathrm{SEM}$ micrograph are almost the same and are homogenously distributed.

\section{AKNOWLEDGEMENT}

I thank Dr. Ridwan (Head of the Center for Science Technology of Advanced MaterialsBATAN) and Dr. Abu Khalid Rivai (Head of the Science and Materials Division) in allowing this work from the PSTBM-BATAN budget. Discussion of scientific and technical background by Dr .rer.nat. Noviyan Darmawan, MS.c, Laras Zulhijah, Bambang Sugeng and Deswita was very useful in completing this study.

\section{REFERENCES}

1. Prasad, S.E., Waechter, D.F., Blacow, R.G., King, H.W., and Yaman, Y., Application of piezoelectrics to smart structures, II ECCOMAS Thematic Conference on Smart Structures and Materials. Lisbon, Portugal, 18-21 July 2005.

2. Kolincio, K., Gdula, K., Mielewczyk-Gryń, A., Izdebski, T., and Gazda, M., Molten Salt Synthesis of Conducting and Superconducting Ceramics, Acta Physica Polonica A, vol. 118., no. 2, pp. 326 327, 2010.

3. Liu, X., et al., p-Type CaFe2O4 semiconductor nanorods controllably synthesized by Molten Salt method, J. Energy Chem., vol. 25, no. 3, pp. 381386, 2016.

4. Liu, X., Fechler, N., and Antonietti, M., Carbon nanostructures, Chem Soc Rev, vol. 42, pp. 8237 - 8265, 2013.

5. Delpech, S., Cabet, C., Slim, C., and Picard, G.S., Molten fluorides for nuclear applications, Materials Today, vol. 13, no. 12, pp. $34-41,2016$.
6. Ahda, S., Misfadhila, S., Parikin, P., and Putra, T.Y.S.P., Molten Salt Synthesis and Structural Characterization of BaTiO 3 Nanocrystal Ceramics, IOP Conference Series: Materials Science and Engineering, vol. 176, no. 1, pp. 012048 , 2017.

7. Benchikhi, M., El, R., Er-rakho, L., Jacques, J., and Durand, B., Lowtemperature Molten Salt synthesis and characterization of Cu2ZnSnS4 ultrafine powders, Optik, vol. 138, pp. 568-572, 2017.

8. Lambert, H., Kerry, T., and Sharrad, C.A., Preparation of uranium(III) in a molten chloride salt: a redox mechanistic study, Journal of Radioanalytical and Nuclear Chemistry, vol. 317, no. 2, pp. 925 - 932, 2018.

9. Zulhijah, L., Sintesis Timbal Zirkonat Titanat dengan Metode Lelehan Garam, Thesis (S1), Departement of Chemistry, Bogor Agricultural Institute, 2017.

10. Kniess, C.T., De Lima, J.C., and Prates, P.B., The Quantification of Crystalline Phases in Materials: Applications of Rietveld Method, Volodymyr Shatokha (Eds.), Sintering - Methods and Products, March 2012.

11. Tamer, M., Quantitative Phase Analysis Based on Rietveld Structure Refinement for Carbonate Rocks, Journal of Modern Physics, vol. 4, no. 8, pp. 1149-1157, 2013.

12. Necira, Z., Boutarfaia, A., Abba, M., and Abdessalem, N., Synthesis of PZT powder by conventional method at various conditions, in EPJ Web of Conferences, vol. 29, no. 00038, pp. 1 7. 2012.

13. Brust, S., Transformation of Surface Oxides during Vacuum Heat Treatment of a Powder Metallurgical Hot Work Tool, Department of Materials and Manufacturing Technology, Diploma work No. 109/2013, Chalmers University of Technology Gothenburg, Sweden, 2013. 